\title{
Review
}

\section{S-Mercuration of cellular proteins by methylmercury and its toxicological implications}

\author{
Hironori Kanda' ${ }^{1}$ Yasuhiro Shinkai ${ }^{2}$ and Yoshito Kumagai ${ }^{2}$ \\ ${ }^{1}$ Doctoral Program in Biomedical Sciences, Graduate School of Comprehensive Human Sciences, \\ University of Tsukuba, Tsukuba, Ibaraki 305-8575, Japan \\ ${ }^{2}$ Environmental Biology Laboratory, Faculty of Medicine, University of Tsukuba, Tsukuba, Ibaraki 305-8575, Japan
}

(Received July 11, 2014; Accepted July 16, 2014)

\begin{abstract}
The accumulation of methylmercury (MeHg) through the daily consumption of large predatory fish poses potential health risks. $\mathrm{MeHg}$ has been found to cause Minamata disease, but the full nature of $\mathrm{MeHg}$ toxicity remains unclear. Because of its chemical properties, $\mathrm{MeHg}$ covalently binds to cellular proteins through their reactive thiols, referred to as $S$-mercuration, resulting in the formation of protein adducts. In this review, we summarize how the $S$-mercuration of cellular proteins could be involved in the major mechanisms that have been suggested to underlie MeHg toxicity. Additionally, we introduce our attempts to identify cases of $S$-mercuration for the research to reveal the true nature of $\mathrm{MeHg}$ toxicity.
\end{abstract}

Key words: Methylmercury, Cysteine, Thiol, Covalent binding, Protein

\section{INTRODUCTION}

Many humans have unknowingly accumulated methylmercury $(\mathrm{MeHg})$, which is an environmental electrophile, in the body. Mercury is widespread and persistent in the environment, and its use in many products and the emission of mercury from combustion processes have resulted in chronic environmental exposure around the world. Once in the environment, mercury can be converted into $\mathrm{MeHg}$, which can bioaccumulate and biomagnify through the food chain. There have been concerns about health effects, including damage to the central nervous system (Chang, 1990; Shimai and Satoh, 1985), caused by the accumulation of $\mathrm{MeHg}$ through the daily consumption of large predatory fish. This does not occur under conditions typical for most people, however, in a particular incident, $\mathrm{MeHg}$ was released from a chemical plant and was bioaccumulated by fish and shellfish in Minamata Bay. This resulted in people consuming fish and shellfish from that bay experiencing mercury poisoning, which has since been referred to as Minamata disease. Despite it having been more than half a century since Minamata disease was discovered, the molecular mechanisms underlying the toxic effects of $\mathrm{MeHg}$ are still poorly understood, and more research is required to improve our understanding of the mechanisms involved.
There are about 214,000 cysteine residues encoded in the human genome (Jones, 2008). Cysteine residues are found at the active sites of many enzymes, and they regulate the functions and maintain the conformations of the proteins. Most cysteine residues are buried within the molecule and form disulfide bonds to maintain the structure of the protein. They can, alternatively, serve as ligands for zinc ions $\left(\mathrm{Zn}^{2+}\right)$. Between $10 \%$ and $20 \%$ of the thiol groups in proteins are dissociated, as thiolate anions, under physiological conditions because their $\mathrm{pKa}$ value is low, and this means that they can be potential targets for electrophiles that have low electron densities. For this reason, exogenous electrophiles could cause accidental chemical modifications of proteins (Kumagai and Sumi, 2007; Kumagai et al., 2012). MeHg has a particularly high association constant for thiols $\left(10^{15}-10^{16}\right.$; Table 1) (Simpson, 1961), and its chemical properties allow $\mathrm{MeHg}$ to become covalently bounded to protein thiols in the body, a modification that is termed "S-mercuration." The cellular response to electrophiles is typically biphasic, with the activation of protective signaling pathways occurring at low concentrations and cell death occurring at higher concentrations (Levonen et al., 2014). Unintentional $S$-mercuration disrupts biological homeostasis, and this is thought to be associated, at least in part, with the onset of MeHg toxicity (Fig. 1).

Correspondence: Yoshito Kumagai (E-mail: yk-em-tu@md.tsukuba.ac.jp) 
Table 1. Association constants for $\mathrm{MeHg}$ and various ligands

\begin{tabular}{lc}
\hline Ligand & $\begin{array}{c}\text { Association constant } \\
\text { (logarithm) }\end{array}$ \\
\hline $\mathrm{SH}$ (Cysteine) & 15.7 \\
$\mathrm{NH}_{2}$ (Histidine) & 8.8 \\
$\mathrm{NH}_{3}$ & 8.4 \\
Imidazole & 7.3 \\
\hline
\end{tabular}

Partially reprinted from Simpson, 1961.

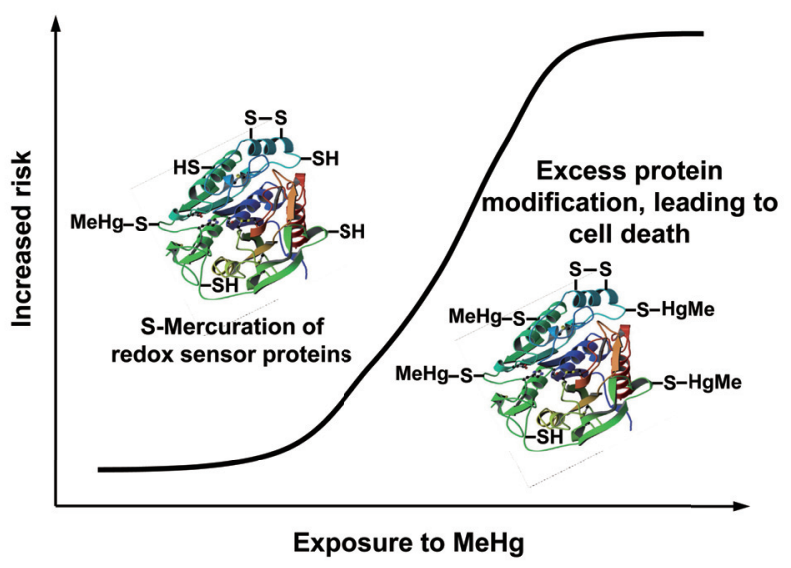

Fig. 1. Unintentional toxicity caused by $\mathrm{MeHg}$ mediated $S$-mercuration. The unintentional $S$-mercuration of cellular proteins by $\mathrm{MeHg}$ at high concentrations leads to cell death, whereas the $S$-mercuration of redox sensor proteins could activate electrophilic signal transduction pathways for cell survival.

As described above, it has been well known for a long time that $\mathrm{MeHg}$ causes the $S$-mercuration of cellular proteins. However, the toxicological effects of $S$-mercuration have been assessed in detail in very few publications. Here, we wish to assess what has become clear about the relationship between the $S$-mercuration of proteins and the onset of toxic effects. To achieve this, we will examine the types of $S$-mercurated proteins that it has been suggested could be involved in the main mechanisms that underlie $\mathrm{MeHg}$ toxicity. We will also introduce our attempts to identify cases of $S$-mercuration.

\section{MAJOR MECHANISMS UNDERLYING METHYLMERCURY TOXICITY}

To determine the major mechanisms that have been suggested to underlie MeHg toxicity, we searched the lit- erature published up to May 2014 for the terms "methylmercury", "mechanism", and "review" using PubMed. A total of 30 publications matching the search terms were identified, and nine of them were found to include a discussion of the mechanisms involved in $\mathrm{MeHg}$ toxicity. We found that five major mechanisms underlying $\mathrm{MeHg}$ toxicity have been identified, and these are summarized in Table 2, along with the factors associated with those mechanisms that were mentioned in the articles. The main mechanisms that have been identified involve oxidative stress and changes in the intracellular concentrations of calcium ions $\left(\mathrm{Ca}^{2+}\right)$. An example of another type of impaired signaling that was suggested to be caused by $\mathrm{MeHg}$ was the inhibition of glutamate uptake. The inhibition of protein synthesis and the disruption of microtubules as the well-known mechanisms were also extracted. According to the textbook "Toxicological Effects of Methylmercury", published by the US National Research Council's Board on Environmental Studies and Toxicology (Committee on the Toxicological Effects of Methylmercury, 2000), mitochondrial changes, the induction of lipid peroxidation, microtubule disruption, and disrupted protein synthesis have been proposed as being possible mechanisms for $\mathrm{MeHg}$ toxicity. These mechanisms are similar to those found from the published literature identified in our search. Protein inhibition was the most common factor that was mentioned in the articles that we inspected.

\section{THE RELATIONSHIP BETWEEN CELLULAR DYSFUNCTION BY METHYLMERCURY AND S-MERCURATION OF CELLULAR PROTEINS}

We attempted to assess the mechanisms through which the $S$-mercuration of cellular proteins could be involved in the cellular dysfunction described above, using even publications that had not actually been referred to in the nine most relevant publications that we had identified. The cellular proteins that can potentially be $S$-mercurated are summarized in Table 2, and they are shown schematically in Fig. 2.

\section{Oxidative stress and $S$-mercuration}

Oxidative stress is a disturbance in the redox status (the balance between oxidants and antioxidants) in the body. $\mathrm{MeHg}$ increases the production of reactive oxygen species (ROS) and the degree to which lipids are peroxidized (Ali et al., 1992; Dreiem and Seegal, 2007; Garg and Chang, 2006; LeBel et al., 1990, 1992; Lee et al., 2009; Mori et al., 2007; Yin et al., 2007; Yonaha et al., 1983). Antioxidant enzymes such as superoxide dismutase (SOD), cat- 
Protein $S$-mercuration and toxic effects by methylmercury

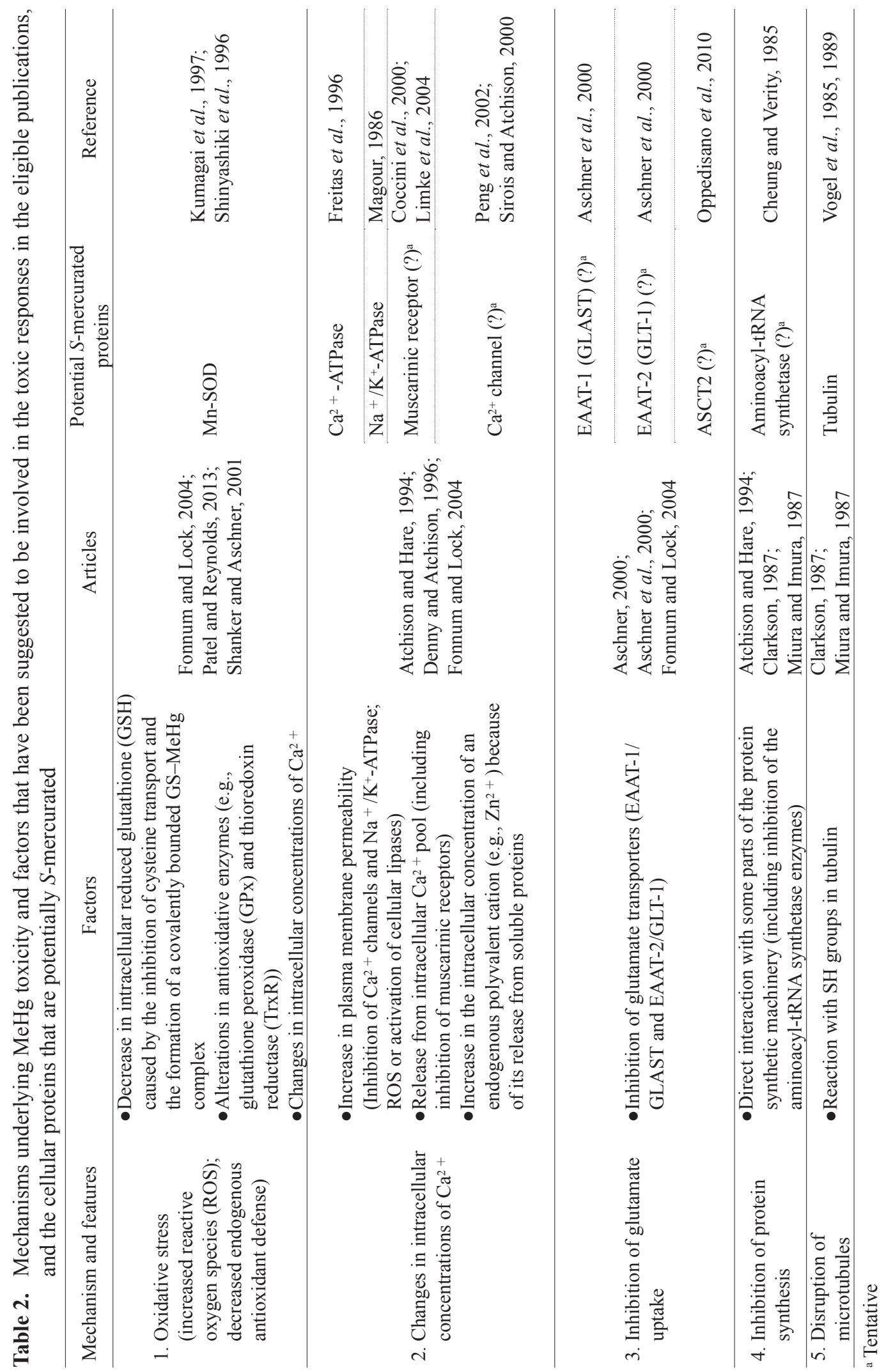

Vol. 39 No. 5 


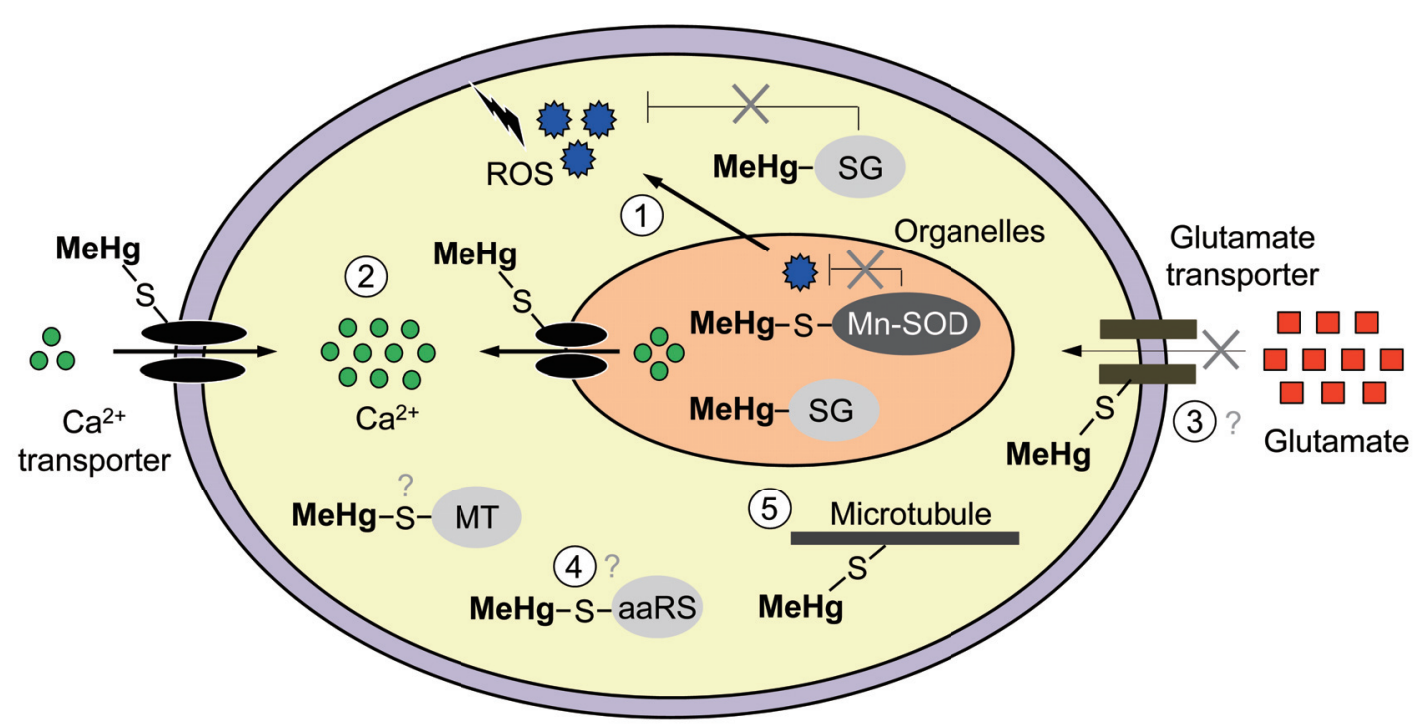

Fig. 2. Schematic of the potential $S$-mercurated cellular proteins associated with toxicity caused by MeHg. The circled numbers indicate the relevant numbered part of the text in Table 2. MeHg causes (1) oxidative stress, (2) changes in intracellular $\mathrm{Ca}^{2+}$ concentrations, (3) inhibition of glutamate uptake, (4) inhibition of protein synthesis, and (5) disruption of microtubules. These events may be due, at least in part, to MeHg causing the $S$-mercuration of (1) Mn-SOD in the mitochondria, (2) $\mathrm{Ca}^{2+}$ transporter(s) such as $\mathrm{Ca}^{2+}$-ATPase and $\mathrm{Na}^{+} / \mathrm{K}^{+}$-ATPase in the plasma membranes and membranes of intracellular organelles (such as the endoplasmic reticulum and the mitochondria), (3) glutamate transporter(s), (4) amino-acyl-tRNA synthetase (aaRS), and (5) tubulin. MeHg-SG means the MeHg and GSH complex. MT stands for metallothionein.

alase, and glutathione peroxidase (GPx) play important roles in scavenging oxidants and preventing cell injury. The brain is particularly sensitive to oxidative damage because it contains many oxidizable substrates, such as lipids (Halliwell, 1992), with low SOD and GPx activities (Mori et al., 2007). We summarize the effect MeHg has on these antioxidant enzymes below.

Yee and Choi (1994) found a marked decrease in the total SOD activity in mouse brains when the mice had been treated with $\mathrm{MeHg}$ for a prolonged period (at 2.5 $\mathrm{mg} / \mathrm{kg} /$ day for 7 days). The authors didn't determine which isozyme was involved in the enzyme loss, but eukaryotic cells contain two types of SODs, copper and zinc SOD (Cu,Zn-SOD) and manganese SOD (Mn-SOD). We later found that Mn-SOD is susceptible to being modified by $\mathrm{MeHg}$ and that $\mathrm{Cu}, \mathrm{Zn}-\mathrm{SOD}$ is not (Shinyashiki et al., 1996). Exposing mice to $\mathrm{MeHg}$ at a dose of $10 \mathrm{mg} / \mathrm{kg}$ only once resulted in a time-dependent decrease in $\mathrm{Mn}$ SOD activity but had little effect on $\mathrm{Cu}, \mathrm{Zn}$-SOD activity in the brain. Mn-SOD is found in mitochondria, in which more than $90 \%$ of the oxygen provided to a cell is consumed and in which ROS are generated. The importance of Mn-SOD in protecting against $\mathrm{MeHg}$ toxicity was reported by Naganuma et al. (1998). They found that the sensitivity of HeLa cells to $\mathrm{MeHg}$ was decreased by the overexpression of Mn-SOD, suggesting that the formation of superoxide anions in the mitochondria might be involved in the mechanism(s) involved in the cytotoxicity of MeHg. We have attempted to examine the mechanism involved in the relationship between Mn-SOD and MeHg (Kumagai et al., 1997; Shinyashiki et al., 1996). Levels of mRNA and protein synthesis for Mn-SOD were unaffected by $\mathrm{MeHg}$ administration. The direct effect of MeHg on the Mn-SOD and Cu,Zn-SOD activities was further examined using purified enzyme preparations. MeHg caused a facile reduction in Mn-SOD activity but not that of $\mathrm{Cu}, \mathrm{Zn}-\mathrm{SOD}$. A combination of isoelectric focusing agarose gel electrophoresis and synchrotron radiation $\mathrm{X}$-ray fluorescence analysis revealed that Mn-SOD rather than $\mathrm{Cu}, \mathrm{Zn}-\mathrm{SOD}$ underwent modification by MeHg. The SH groups in both Cys 140 and Cys 196 in Mn-SOD are exposed at the subunit surface. Experiments involving thiol titration with Ellman's reagent and the purification of digested fragments of human Mn-SOD using thiol-Sepharose column chromatography, each followed by amino acid sequence determination, indicated that Cys196, but not Cys140, is the reactive sulfhydryl (Matsuda et al., 1990). Therefore, oxidative stress caused 
Protein $S$-mercuration and toxic effects by methylmercury

by $\mathrm{MeHg}$ is at least partly due to the $S$-mercuration of Mn-SOD, presumably through Cys196.

In addition to this SOD-related research, it has been found in a number of studies that decreased GPx activity in the brains was caused by the mice being given $\mathrm{MeHg}$ at a concentration of $40 \mathrm{mg} / \mathrm{L}$ in drinking water for several weeks (Carvalho et al., 2007; Farina et al., 2003b; Franco et al., 2009; Glaser et al., 2010). Stringari et al. (2008) reported that exposing pregnant mice to $\mathrm{MeHg}$ at concentrations of 1,3 , and $10 \mathrm{mg} / \mathrm{L}$ in drinking water induced a dose-dependent and long-lasting inhibitory effect on the occurrence of cerebral antioxidant enzymes, such as GPx, which is a developmental phenomenon, in their pups. There have also been many reports of $\mathrm{MeHg}$ causing decreased GPx activity in vitro (Farina et al., 2009; Hirota et al., 1980; Kromidas et al., 1990). Farina et al. (2009) reported that the overexpression of GPx1, which is the most abundant version of GPx, prevented $\mathrm{MeHg}$-induced neuronal death, indicating that GPx1 is an important molecular target that is involved in MeHg-induced neurotoxicity. They didn't determine how GPx1 was inhibited, but suggested that selenol groups (which have lower $\mathrm{pKa}$ values than do thiol groups) in the enzyme were involved. However, thiols are much more abundant than selenols (Farina et al., 2011). In fact, thiol groups can be found in both low-molecularweight (mainly reduced glutathione, GSH) and high-molecular-weight proteins, whereas selenol groups are found only in a restricted group of selenoproteins (Araie and Shiraiwa, 2009; Lobanov et al., 2009). Consequently, $\mathrm{MeHg}$ is expected to be found primarily in thiol-containing proteins (and much less in selenol-containing proteins) in edible fish muscles, which are the most important environmental sources of $\mathrm{MeHg}$ to humans (Farina et al., 2011). $\mathrm{MeHg}$ has also been found to cause the inactivation of thioredoxin reductase (another selenoprotein; TrxR) both in vivo and in vitro (Branco et al., 2011; Carvalho et al., 2011; Wagner et al., 2010). It has been suggested that the Cys497 and selenocysteine 498 residues in reduced TrxR will be the first moieties to be affected by MeHg because of the presence of selenol groups in the selenocysteine residue (Carvalho et al., 2011), but the results obtained with $\mathrm{MeHg}$-inhibited TrxR indicate that the presence of selenite cannot prevent the loss of activity caused by $\mathrm{MeHg}$.

There is little doubt that GSH suppresses the $S$-mercuration of proteins inside cells by forming a $\mathrm{MeHg}-$ GSH complex (MeHg-SG). There is a cellular response to $\mathrm{MeHg}$ through the activation of transcription factor NF-E2-related factor 2 (Nrf2) coupled to the $S$-mercuration of its negative regulator, Kelch-like ECH-associat- ed protein 1 (Keap1) (Kumagai et al., 2013) to promote the formation of $\mathrm{MeHg}-\mathrm{SG}$ and its excretion into extracellular space. A very interesting aspect of "thiol biology" has recently been described. We have reported that reactive sulfur species (RSS) such as hydrogen sulfide anions (HS-), persulfides, and polysulfides, have critical regulatory functions by performing redox signaling and by scavenging electrophiles (Ida et al., 2014; Nishida et al., 2012). In fact, HS- (Yoshida et al., 2011), glutathione persulfide (GS-SH) and glutathione trisulfide (GS-S-SG) (E. Yoshida, unpublished observations) as models for endogenous RSS can react with $\mathrm{MeHg}$ to form bismethylmercury sulfide $\left((\mathrm{MeHg})_{2} \mathrm{~S}\right)$, which has little capability to $S$-mercurate proteins and is much less cytotoxic than $\mathrm{MeHg}$.

Metallothioneins (MTs) are another group of proteins that are known to play roles protecting cells. Because MTs have very high affinities for $\mathrm{MeHg}$ by virtue of the large numbers of thiol groups $(-\mathrm{SH})$ content (Oliveira et al., 1998), the formation of $\mathrm{MeHg}-\mathrm{MT}$ complexes may keep $\mathrm{MeHg}$ in a relatively nontoxic form, thereby protecting cells from the cytotoxic effects of $\mathrm{MeHg}$ (Aschner et al., 1997). Decreased concentrations of GSH and/or MT could cause cells to be more susceptible to the effects of MeHg (Hirooka et al., 2010), and the disturbances in cellular signal transduction pathways could cause adverse events including cell death.

\section{Changes in intracellular calcium ion concentrations and S-mercuration}

The $\mathrm{Ca}^{2+}$ play an important role in signal transduction pathways, which affect every aspect of the life and death of a cell (Clapham, 2007). The $\mathrm{Ca}^{2+}$ concentration is normally about 10,000 times higher outside cells than in cytoplasm. $\mathrm{Ca}^{2+}$ concentrations are also much higher in some intracellular organelles, such as the endoplasmic reticulum (ER), than in cytoplasm. It has been found in a number of studies that $\mathrm{MeHg}$ causes the intracellular $\mathrm{Ca}^{2+}$ concentration to increase, and this effect is possibly caused by an influx of $\mathrm{Ca}^{2+}$ from outside the cells and by the release of $\mathrm{Ca}^{2+}$ from intracellular stores, such as the ER and the mitochondria (Dreiem and Seegal, 2007; Hare et al., 1993; Limke and Atchison, 2002; Limke et al., 2003; Minnema et al., 1989; Sarafian, 1993; Tan et al., 1993). The disruption of $\mathrm{Ca}^{2+}$ handling could ultimately lead to cell death. The increase in the intracellular $\mathrm{Ca}^{2+}$ concentration is believed to be caused by increased permeability of the plasma membrane and intracellular membranes to $\mathrm{Ca}^{2+}$. In addition to their lipid components, biological membranes contain proteins, so the $S$-mercuration of proteins involved in the transport of cations, includ- 
ing $\mathrm{Ca}^{2+}$, could affect this transport across the membrane, increasing the permeability of the membrane and disrupting cellular functions (Jacob and Jandl, 1962). $\mathrm{Ca}^{2+}$-ATPase pumps in plasma membranes and in ER membranes maintain a low $\mathrm{Ca}^{2+}$ concentration by transporting $\mathrm{Ca}^{2+}$ away from the cytosol. Chiu et al. (1983) and Freitas et al. (1996) found that $\mathrm{MeHg}$ inhibits $\mathrm{Ca}^{2+}$ pumps such as $\mathrm{Ca}^{2+}$-ATPase presumably through $S$-mercuration, and that this results in the $\mathrm{Ca}^{2+}$ fluxes across the membranes being altered. $\mathrm{Na}^{+} / \mathrm{K}^{+}$-ATPase indirectly regulates intracellular $\mathrm{Ca}^{2+}$ concentrations by controlling the $\mathrm{Na}^{+}$gradient. Magour (1986) found that MeHg inhibits brain synaptosomal $\mathrm{Na}^{+} / \mathrm{K}^{+}$-ATPase, presumably by $S$-mercurating the protein. It has also been shown that exposing rats to $\mathrm{MeHg}$ results in the $\mathrm{Na}^{+} / \mathrm{K}^{+}$-ATPase activity in the cerebral cortex being inhibited (Chuu et al., 2001). Therefore, it can be concluded that $\mathrm{MeHg}$ has the potential to inhibit signal transduction activity by $S$-mercurating transport proteins that are involved in the $\mathrm{Ca}^{2+}$ messenger functions. Interestingly, the results of a study performed by Berstein et al. (1988) suggested that the redox states of the thiol groups in muscarinic receptor molecules are important in determining their affinities for ligands. Since then, it has been found that $\mathrm{MeHg}$ inhibits muscarinic receptors (Coccini et al., 2000) and that $\mathrm{MeHg}$ can interact with muscarinic receptors to cause $\mathrm{Ca}^{2+}$ to be released from the ER (Limke et al., 2004). Sirois and Atchison (2000) and Peng et al. (2002) showed that $\mathrm{MeHg}$ affects $\mathrm{Ca}^{2+}$ channels, but the mechanism responsible for this effect is still unknown. It is interesting to note that $\mathrm{Ca}^{2+}$ channel blockers were found to prevent the body weight from decreasing and the appearance of symptoms of neurological disorders in rats treated with $\mathrm{MeHg}$ (Sakamoto et al., 1996). It is well recognized that disrupting calcium homeostasis in the ER causes ER stress (Mekahli et al., 2011). Consistent with this, MeHg was found to induce the expression of glucose-regulated protein 78, a maker of ER stress, in the brain cortex of rats (Zhang et al., 2013).

After the initial increase in the intracellular $\mathrm{Ca}^{2+}$ concentration caused by cells being exposed to $\mathrm{MeHg}$, modest increases in intracellular $\mathrm{Zn}^{2+}$ have been found (Atchison and Hare, 1994; Denny and Atchison, 1996), although the relevance of this finding to the toxicity of $\mathrm{MeHg}$ is unknown. The extra free $\mathrm{Zn}^{2+}$ are potentially derived from proteins that contain $\mathrm{Zn}^{2+}$ being $S$-mercurated by $\mathrm{MeHg}$, because under normal conditions the free $\mathrm{Zn}^{2+}$ concentrations in cells are low and most $\mathrm{Zn}^{2+}$ are bound to intracellular proteins (Cuajungco and Lees, 1997). As an example, we will later describe the $S$-mercuration of the zinc metalloenzyme sorbitol dehydrogenase (SDH), which leads to $\mathrm{Zn}^{2+}$ being released from the active site in the $\mathrm{SDH}$.

Taking all of the available information into account, it appears that the $S$-mercuration of cellular proteins by $\mathrm{MeHg}$ is possibly associated with increased intracellular $\mathrm{Ca}^{2+}$ concentrations, and this is believed to be an important factor in the onset of $\mathrm{MeHg}$ toxicity.

\section{The inhibition of glutamate uptake and S-mercuration}

It is widely known that $\mathrm{MeHg}$ alters glutamate homeostasis (Farina et al., 2003a, 2003b; Manfroi et al., 2004; Yin et al., 2007). Glutamate is the predominant excitatory neurotransmitter, but it is also a potent neurotoxin when it is present in excess. MeHg inhibits the glutamate transporters GLAST (EAAT-1) and GLT-1 (EAAT-2) in astrocytes, leading to a decrease in glutamate uptake and an increase in the glutamate concentration in the extracellular fluid (Aschner et al., 2000). This could sensitize neurons to excitotoxic injury.

Sulfhydryl groups in membrane proteins have been shown to play critical functional roles in the membrane behavior (Aizenman et al., 1989; Braestrup and Andersen, 1987; Kiskin et al., 1986; Laube et al., 1993; Ruppersberg et al., 1991; Sidhu et al., 1986). The mechanisms associated with the inhibition of glutamate uptake by $\mathrm{MeHg}$ are unknown, but Trotti et al. (1997a, 1997b, 1998) found that the redox interconversion of cysteines in glutamate transporters (including GLAST and GLT1), induced by the thiol oxidizing agent 5,5'-dithio-bis(2-nitrobenzoic) acid and the thiol reducing agent dithiothreitol, causes changes in glutamate uptake rates. The glutamine/glutamate transporter (ASCT2) has also been found to be inhibited by MeHg through $S$-mercuration (Oppedisano et al., 2010). Thus, the inhibition of glutamate uptake is thought to be attributable, at least in part, to the $S$-mercuration of glutamate transporters. $\mathrm{MeHg}$ also causes increased amounts of other neurotransmitters, such as dopamine and acetylcholine, to be released (Faro et al., 2000, 2002; Minnema et al., 1989), and it has been suggested that the $S$-mercuration of membrane proteins may cause this effect (Faro et al., 2005; Fonfría et al., 2001).

\section{The inhibition of protein synthesis and $S$-mercuration}

It has long been known that protein synthesis is inhibited by $\mathrm{MeHg}$ before neurological symptoms can be found (Cavanagh and Chen, 1971; Yoshino et al., 1966). This is believed to be primarily caused by $\mathrm{MeHg}$ inhibiting the activities of aminoacyl-tRNA synthetases (aaRSs) (Cheung and Verity, 1985), which are enzymes that charge specific tRNAs with their cognate amino acids and 
Protein $S$-mercuration and toxic effects by methylmercury

play essential roles in the initial steps involved in protein synthesis. The thiol groups in aaRSs are involved in the activities of the enzymes (Murayama et al., 1975). The mechanism through which $\mathrm{MeHg}$ inhibits aaRS activity has yet to be determined, but the $S$-mercuration of aaRSs by $\mathrm{MeHg}$ is thought to be associated, at least in part, with the inhibition of protein synthesis.

\section{The disruption of microtubules and S-mercuration}

Microtubules are structural components that are important in the cell division process, and also play essential roles in the maintenance of cell shape and cell motility. Administering $\mathrm{MeHg}$ to rats resulted in disturbances in the integrities of the microtubules in the nervous system (Kinoshita et al., 1999). It has also been found that $\mathrm{MeHg}$ causes the abnormal migration of neurons in the brain (Choi et al., 1978). The arresting of the G2/Mphase because of microtubules being disrupted may be an important factor in $\mathrm{MeHg}$ leading to apoptosis (Miura K. et al., 1999). MeHg has long been known to be a potent inhibitor of microtubule polymerization, and this effect is presumably caused by the $S$-mercuration of the microtubules by $\mathrm{MeHg}$ (Abe et al., 1975; Sager et al., 1983; Vogel et al., 1985, 1989). Vogel et al. (1989) found that there is a class of binding sites that have high affinities for $\mathrm{MeHg}$ on tubulin and that $\mathrm{MeHg}$ binds to tubulin stoichiometrically within microtubules. Tubulin has been found to contain thiols with low $\mathrm{pKa}$ values (Britto et al., 2002).

\section{ATTEMPTS TO IDENTIFY CASES OF THE S-MERCURATION OF PROTEINS}

The biological factors that are altered by $\mathrm{MeHg}$ have been explored with the aim of shedding light on the molecular mechanisms that underlie $\mathrm{MeHg}$ toxicity (Hwang et al., 2011a, 2013a; Hwang and Naganuma, 2006; Kim et al., 2012, 2013; Lee et al., 2012; Takahashi et al., 2013; Toyama et al., 2011). Furthermore, the research group led by Dr. Naganuma has found a large number of proteins that are resistant or hypersensitive to MeHg (Hwang et al., 2007, 2009, 2010a, 2010b, 2010c, $2011 b, 2012 a, 2012 b, 2013 b)$. For example, they found that L-glutamine:D-fructose-6-phosphate amidotransferase (GFAT), which is an essential enzyme for catalyzing the synthesis of glucosamine-6-phosphate from glutamine and fructose-6-phosphate, is a factor that confers MeHg-resistance and that GFAT is the intracellular target molecule for $\mathrm{MeHg}$ toxicity (Miura N. et al., 1999; Naganuma et al., 2000). The effects of $\mathrm{MeHg}$ on the activities of GFAT and other SH-containing enzymes were compared in that work, and the GFAT activity was found to be almost completely inhibited by $\mathrm{MeHg}$ when almost no effects on the other SH-containing enzymes were found. This suggests that $\mathrm{MeHg}$ has a high affinity for GFAT and specifically inhibits its activity.

As mentioned above, the true cause of $\mathrm{MeHg}$ toxicity is likely to be the $S$-mercuration of proteins. However, few studies have been performed using a "chemical biology approach" even though such studies will be required to absolutely identify the cause of $\mathrm{MeHg}$ toxicity. One reason for the lack of such studies is that methods for identifying the $S$-mercuration of proteins by $\mathrm{MeHg}$ have not been available. A method in which the cysteine-alkylating agent $N$-ethylmaleimide (NEM) is used indirectly or the radiolabeled compound is used directly has only become available until recent years. We used a new method for detecting the $S$-mercuration of proteins (involving column chromatography, a biotin-PEAC $\mathrm{C}_{5}$-maleimide (BPM)-labeling assay, and matrix-assisted laser desorption/ionization time-of-flight mass spectrometry (MALDI-TOF/MS)) to screen for proteins that are targeted by $\mathrm{MeHg}$, focusing on the conformational changes found in proteins when they become $S$-mercurated and then aggregated. There is not enough evidence to identify the toxicological effects of $\mathrm{MeHg}$ in the liver because the main concern regarding $\mathrm{MeHg}$ exposure is neurotoxicity, but $\mathrm{MeHg}$ has been found to accumulate strongly in the liver as well as in the brain (Yasutake et al., 1997). Therefore, we attempted to detect new target proteins for $\mathrm{MeHg}$ in the liver. We will introduce each approach and the proteins that were screened below.

\section{Arginase I}

Arginase I is expressed almost exclusively in the liver, where it is an essential enzyme in the urea cycle, which detoxifies ammonia. Arginase I has a binuclear Mn cluster that provides full catalytic activity and stability to the enzyme. We hypothesized that $\mathrm{MeHg}$ could interact with arginase I through covalent modification, resulting in alterations in not only its catalytic activity but also in the Mn concentration in the liver when in vivo exposure to $\mathrm{MeHg}$ occurs. Both arginase I activities and Mn concentrations in the liver fell to approximately $50 \%$ of the control values (Kanda et al., 2008). With purified arginase I, we found that interaction of $\mathrm{MeHg}$ with arginase I caused the aggregation of arginase I as evaluated by centrifugation and subsequent precipitation, and the catalytic activity of the arginase I to decrease. This same phenomenon occurred when NEM was used instead of MeHg, suggesting that the covalent modification of thiolate ions in rat liver arginase I led to the aggregation of the protein. Mn 
ions were released from purified arginase I when its activity was inhibited by exposure to $\mathrm{MeHg}$ in vitro. To confirm the possibility that $\mathrm{MeHg}$ is able to react with reactive thiols in arginase I, we examined the elution behavior of arginase I using Affi-Gel 501 resin coupled to organomercurial (Kanda et al., 2008) (Fig. 3). When purified arginase I was poured onto a column packed with AffiGel 501, this protein was tightly bound to the resin. No protein was eluted by $0.5 \mathrm{M} \mathrm{NaCl}$ followed by $10 \mathrm{mM}$ histidine and then $0.05 \%$ Tween 20 . This suggests that the interactions of arginase I with organomercurial were not non-selective binding, hydrophobic interactions, or covalent binding via imidazol groups. However, arginase I was eluted efficiently by $10 \mathrm{mM}$ 2-mercaptoethanol (2-ME), supporting the conclusion that the arginase I was covalently attached to the organomercurial through the reactive thiols in the arginase I. Further research will be required to elucidate the relationship between decreasing arginase I activities, decreasing Mn concentrations in the liver, and $\mathrm{MeHg}$-dependent hepatotoxicity.

\section{Sorbitol dehydrogenase}

In the experiments that we investigated the effect of $\mathrm{MeHg}$ on hepatic arginase I described above, we coincidentally detected other proteins in the same hepatic preparations that also readily underwent covalent modification by $\mathrm{MeHg}$ and subsequently became aggregated (Kanda et al., 2012). The rat hepatic preparation was incubated with different concentrations of $\mathrm{MeHg}(1-200 \mu \mathrm{M})$ at $37^{\circ} \mathrm{C}$ for $1 \mathrm{hr}$, and then each mixture was centrifuged at $12,000 \times \mathrm{g}$ for $10 \mathrm{~min}$. The precipitate was dissolved in $1 \mathrm{mM} \mathrm{GSH} \mathrm{(Fig.} \mathrm{4),} \mathrm{and} \mathrm{the} \mathrm{supernatant} \mathrm{was} \mathrm{elec-}$ trophoresed on SDS-polyacrylamide gel electrophoresis (SDS-PAGE). Four main protein bands, with molecular weights of 42, 39, 30.5, and $30 \mathrm{kDa}$, were detected (Fig. 4). Similar results were found when the thiol-modifying agent NEM was used instead of $\mathrm{MeHg}$, which suggests that the $\mathrm{MeHg}$-mediated aggregation of the proteins was caused by the covalent modification of the protein through its reactive thiol groups. The immunoblot analysis revealed that the protein with a molecular weight of $39 \mathrm{kDa}$ was arginase I. To identify the major protein with a molecular weight of $42 \mathrm{kDa}$, we separated the protein using a two-dimensional (2D) SDS-PAGE and then performed peptide mass fingerprinting using MALDI-TOF/ MS. The protein with a molecular weight of $42 \mathrm{kDa}$ was identified as being SDH, which is a zinc metalloenzyme that catalyzes the conversion of sorbitol into fructose in the presence of $\mathrm{NAD}^{+}$, which is a cofactor.

Using recombinant rat $\mathrm{SDH}$, we found that $\mathrm{MeHg}$ causes (1) the protein to aggregate, (2) zinc ion to be released from the active site, and (3) the catalytic activity to be inhibited. These MeHg-dependent phenomena were blocked when GSH was added, suggesting that the $S$-mercuration of SDH contributed to the effects that were observed. Consistent with this notion, SDH was found to be easily modified by MeHg in tests using the BPM-labeling assay (Toyama et al., 2013) (Fig. 5). In this assay,

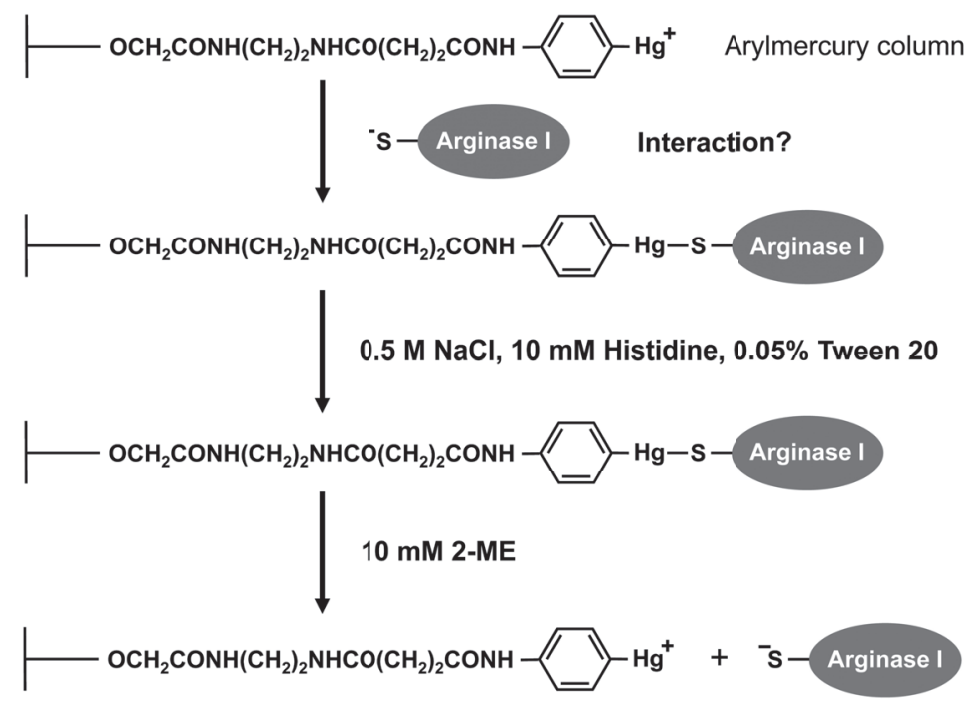

Fig. 3. Schematic of the elution of purified arginase I from an arylmercury column. The purified arginase I protein was applied to the organomercury column (Affi-Gel $501 ; 2.0 \times 1.0 \mathrm{~cm}$, i.d.) and the proteins that bound to the column were eluted using $0.5 \mathrm{M} \mathrm{NaCl}$, then $10 \mathrm{mM}$ histidine, $0.05 \%$ Tween 20 , and finally $10 \mathrm{mM} 2$-mercaptoethanol. 
Protein $S$-mercuration and toxic effects by methylmercury

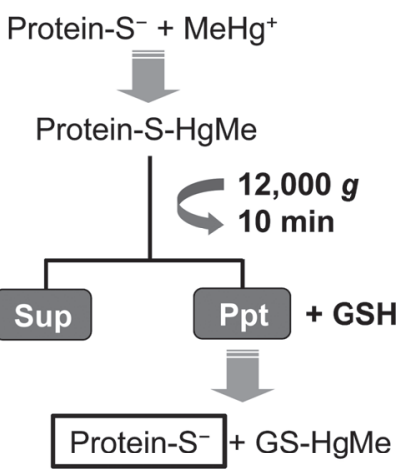

Target molecules?

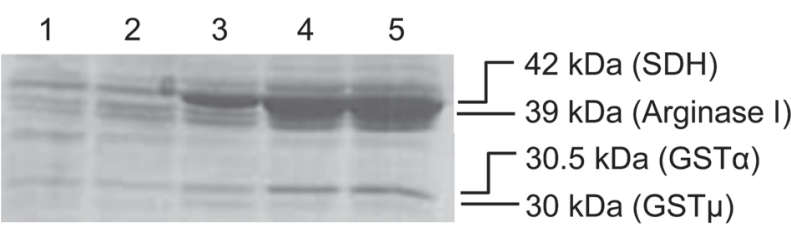

Fig. 4. Screening to identify proteins that underwent aggregation through $S$-mercuration by $\mathrm{MeHg}$ and the target molecules obtained from rat liver preparations. The hepatic preparation was incubated with $\mathrm{MeHg}$ for $1 \mathrm{hr}$ at $37^{\circ} \mathrm{C}$, then the mixture was centrifuged at $12,000 \times \mathrm{g}$ for $10 \mathrm{~min}$, and the precipitate was dissolved in $1 \mathrm{mM} \mathrm{GSH}$. The precipitate was analyzed using SDS-polyacrylamide gel electrophoresis (SDS-PAGE), and the proteins were detected using the silver staining technique. The lane numbers $1,2,3,4$, and 5 correspond to $\mathrm{MeHg}$ concentrations of $0,1,10,100$, and $200 \mu \mathrm{M}$, respectively. Reprinted from Kanda et al., 2012.

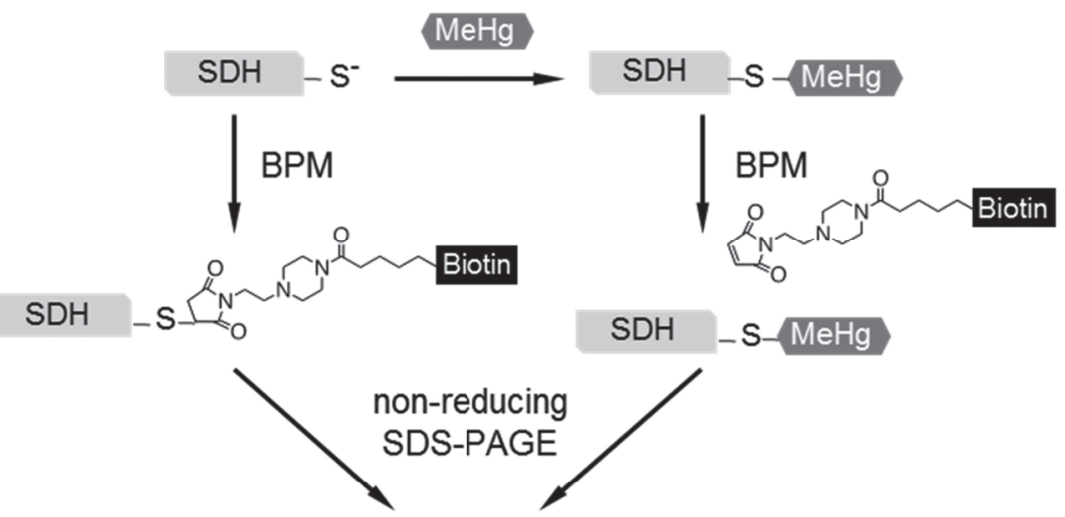

Detected by Avidin-HRP

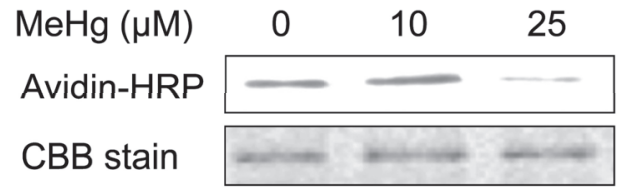

Fig. 5. BPM-labeling assay used to analyze rat SDH treated with $\mathrm{MeHg}$. The assay was used to detect BPM-modified thiols in proteins that had been exposed to MeHg. Recombinant rat SDH $(0.3 \mathrm{mg} / \mathrm{mL})$ was incubated with $\mathrm{MeHg}(10$ or $25 \mu \mathrm{M})$ at $37^{\circ} \mathrm{C}$ for $1 \mathrm{hr}$. Reprinted from Kanda et al., 2012. 


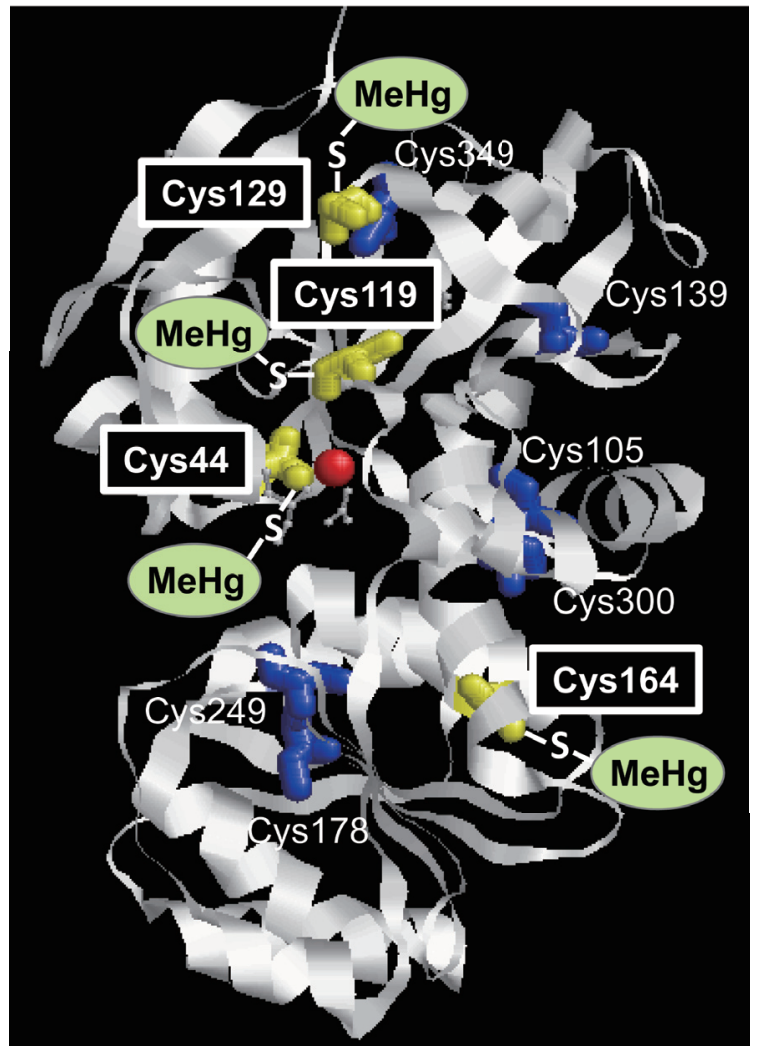

Fig. 6. Sites of MeHg modification in rat SDH. The 3D structure actually shows sheep liver SDH (from the PROTEIN DATA BANK). The image and the color modifications to indicate the cysteine residues were produced using RasMol. The residues in yellow are the sites where $\mathrm{MeHg}$ modifications occurred and the residues in blue are other cysteines. The cysteine residues of rat liver SDH are numbered based on amino-acid sequence homology. The atom in red is zinc.

protein $S$-mercuration by $\mathrm{MeHg}$ can be estimated by a decrease in protein modification by BPM, which is a thiol reactive probe. BPM is a biotinylated-maleimide that is often used to visualize reactive protein thiols using horseradish peroxidase-conjugated streptavidin (avidin-HRP), taking advantage of a better avidin-binding and resistance to extreme changes in temperature and $\mathrm{pH}$. BPM is commercially available and does not require a specific antibody against $\mathrm{MeHg}$. In this system, a decrease in the amount of BPM-binding that occurs reflects a decrease in the number of free thiol groups available. It has been reported that rat SDH has 10 cysteine residues in a subunit, but the MALDI-TOF/MS results suggested that the rat $\mathrm{SDH}$ was $S$-mercurated by $\mathrm{MeHg}$ in four cysteine residues, Cys44, Cys119, Cys129, and Cys164 (Fig. 6).
Serine mutations in Cys44 and Cys129 dramatically blocked the $\mathrm{MeHg}$-mediated aggregation of rat $\mathrm{SDH}$. This suggests that alterations in the three-dimensional structure of this protein that are caused by $S$-mercuration may have been responsible for facilitating the substantial aggregation that was observed. Since Cys44 functions as a ligand for the coordination of the active site zinc ion, it seems likely that the $S$-mercuration of Cys 44 will be a major cause of the release of zinc ion. In our preliminary study, we found that exposing primary mouse hepatocytes to $\mathrm{MeHg}$ resulted in a negligible decrease in cellular SDH activity. Since pretreatment with NAD, which binds closely to Cys44, caused the concentration-dependent inhibition of SDH aggregation by $\mathrm{MeHg}$, the lack of a decrease in cellular SDH activity in the hepatocytes may have been caused by the protective effects of cellular factors not only GSH but also NAD on the covalent modification of cellular $\mathrm{SDH}$ by $\mathrm{MeHg}$.

\section{Glutathione S-transferase}

We also tried to isolate the proteins with molecular weights of 30 and $30.5 \mathrm{kDa}$ using 2D SDS-PAGE and to identify the proteins using MALDI-TOF/MS. The 30 and $30.5 \mathrm{kDa}$ proteins were glutathione $S$-transferase (GST) $\mathrm{Yb}(\mathrm{GST} \mu)$ and GSTYa (GST $\alpha)$, respectively (H. Kanda, unpublished observations). GST is a phase II enzyme that detoxifies a broad range of electrophiles by conjugating them with the reduced form of GSH. The $\mathrm{pKa}$ of GSH is high (9.2) and little GSH is ionized at physiological $\mathrm{pH}$ values, but GST decreases the $\mathrm{pKa}$ of the thiol in GSH in the enzyme-GSH complex. It has been suggested that the cysteine residue(s) in GST are important (Cheng et al., 2001; Katusz et al., 1992), so further research is needed.

\section{CONCLUSIONS}

To truly understand $\mathrm{MeHg}$ toxic effects, the fundamental reason for the effects needs to be found. We found that the $S$-mercuration of cellular proteins, such as Mn-SOD (oxidative stress), membrane proteins such as transporters (impaired signaling), and tubulin (disruption of microtubules), is probably involved in the main mechanisms that have been suggested to underlie MeHg toxicity. Methods for identifying $S$-mercurated proteins are increasingly becoming available, and these methods may allow the mechanisms through which $S$-mercuration is involved in $\mathrm{MeHg}$ toxicity to be understood in the future and the key cellular proteins involved to be identified. 
Protein $S$-mercuration and toxic effects by methylmercury

\section{ACKNOWLEDGMENT}

This work was supported by a Grant-in-Aid (\#25220103) for Scientific Research from the Ministry of Education, Culture, Sports, Science, and Technology of Japan.

Conflict of interest---- The authors declare that there is no conflict of interest.

\section{REFERENCES}

Abe, T., Haga, T. and Kurokawa, M. (1975): Blockage of axoplasmic transport and depolymerisation of reassembled microtubules by methyl mercury. Brain Res., 86, 504-508.

Aizenman, E., Lipton, S.A. and Loring, R.H. (1989): Selective modulation of NMDA responses by reduction and oxidation. Neuron, 2, 1257-1263.

Ali, S.F., LeBel, C.P. and Bondy, S.C. (1992): Reactive oxygen species formation as a biomarker of methylmercury and trimethyltin neurotoxicity. Neurotoxicology, 13, 637-648.

Araie, H. and Shiraiwa, Y. (2009): Selenium utilization strategy by microalgae. Molecules, 14, 4880-4891.

Aschner, M. (2000): Astrocytic swelling, phospholipase A2, glutathione and glutamate: interactions in methylmercury-induced neurotoxicity. Cell. Mol. Biol., 46, 843-854.

Aschner, M., Cherian, M.G., Klaassen, C.D., Palmiter, R.D., Erickson, J.C. and Bush, A.I. (1997): Metallothioneins in brain-the role in physiology and pathology. Toxicol. Appl. Pharmacol., 142, 229-242.

Aschner, M., Yao, C.P., Allen, J.W. and Tan, K.H. (2000): Methylmercury alters glutamate transport in astrocytes. Neurochem. Int., 37, 199-206.

Atchison, W.D. and Hare, M.F. (1994): Mechanisms of methylmercury-induced neurotoxicity. FASEB J., 8, 622-629.

Berstein, G., Haga, K., Haga, T. and Ichiyama, A. (1988): Agonist and antagonist binding of muscarinic acetylcholine receptors purified from porcine brain: interconversion of high- and lowaffinity sites by sulfhydryl reagents. J. Neurochem., 50, 16871694

Braestrup, C. and Andersen, P.H. (1987): Effects of heavy metal cations and other sulfhydryl reagents on brain dopamine D1 receptors: evidence for involvement of a thiol group in the conformation of the active site. J. Neurochem., 48, 1667-1672.

Branco, V., Canário, J., Holmgren, A. and Carvalho, C. (2011): Inhibition of the thioredoxin system in the brain and liver of zebraseabreams exposed to waterborne methylmercury. Toxicol. Appl Pharmacol., 251, 95-103.

Britto, P.J., Knipling, L. and Wolff, J. (2002): The local electrostatic environment determines cysteine reactivity of tubulin. J. Biol. Chem., 277, 29018-29027.

Carvalho, M.C., Franco, J.L., Ghizoni, H., Kobus, K., Nazari, E.M., Rocha, J.B., Nogueira, C.W., Dafre, A.L., Müller, Y.M. and Farina, M. (2007): Effects of 2,3-dimercapto-1-propanesulfonic acid (DMPS) on methylmercury-induced locomotor deficits and cerebellar toxicity in mice. Toxicology, 239, 195-203.

Carvalho, C.M., Lu, J., Zhang, X., Arnér, E.S. and Holmgren, A. (2011): Effects of selenite and chelating agents on mammalian thioredoxin reductase inhibited by mercury: implications for treatment of mercury poisoning. FASEB J., 25, 370-381.

Cavanagh, J.B. and Chen, F.C. (1971): Amino acid incorporation in protein during the "silent phase" before organo-mercury and $p$-bromophenylacetylurea neuropathy in the rat. Acta Neuropathol., 19, 216-224.

Chang, L.W. (1990): The neurotoxicology and pathology of organomercury, organolead, and organotin. J. Toxicol. Sci., 15, 125151.

Cheng, H., Tchaikovskaya, T., Tu, Y.S., Chapman, J., Qian, B., Ching, W.M., Tien, M., Rowe, J.D., Patskovsky, Y.V., Listowsky, I. and Tu, C.P. (2001): Rat glutathione S-transferase M4-4: an isoenzyme with unique structural features including a redox-reactive cysteine-115 residue that forms mixed disulphides with glutathione. Biochem. J., 356, 403-414.

Cheung, M.K. and Verity, M.A. (1985): Experimental methyl mercury neurotoxicity: locus of mercurial inhibition of brain protein synthesis in vivo and in vitro. J. Neurochem., 44, 1799-1808.

Chiu, V.C., Mouring, D. and Haynes, D.H. (1983): Action of mercurials on the active and passive transport properties of sarcoplasmic reticulum. J. Bioenerg. Biomembr., 15, 13-25.

Choi, B.H., Lapham, L.W., Amin-Zaki, L. and Saleem, T. (1978): Abnormal neuronal migration, deranged cerebral cortical organization, and diffuse white matter astrocytosis of human fetal brain: a major effect of methylmercury poisoning in utero. J. Neuropathol. Exp. Neurol., 37, 719-733.

Chuu, J.J., Liu, S.H. and Lin-Shiau, S.Y. (2001): Effects of methyl mercury, mercuric sulfide and cinnabar on active avoidance responses, $\mathrm{Na}^{+} / \mathrm{K}^{+}$-ATPase activities and tissue mercury contents in rats. Proc. Natl. Sci. Counc. Repub. China B, 25, 128-136.

Clapham, D.E. (2007): Calcium signaling. Cell, 131, 1047-1058.

Clarkson, T.W. (1987): Metal toxicity in the central nervous system. Environ. Health Perspect., 75, 59-64.

Coccini, T., Randine, G., Candura, S.M., Nappi, R.E., Prockop, L.D. and Manzo, L. (2000): Low-level exposure to methylmercury modifies muscarinic cholinergic receptor binding characteristics in rat brain and lymphocytes: physiologic implications and new opportunities in biologic monitoring. Environ. Health Perspect., 108, 29-33.

Committee on the Toxicological Effects of Methylmercury (2000): Toxicological effects of methylmercury, pp.55, National Academy Press. Washington, DC.

Cuajungco, M.P. and Lees, G.J. (1997): Zinc metabolism in the brain: relevance to human neurodegenerative disorders. Neurobiol. Dis., 4, 137-169.

Denny, M.F. and Atchison, W.D. (1996): Mercurial-induced alterations in neuronal divalent cation homeostasis. Neurotoxicology, 17, 47-61.

Dreiem, A. and Seegal, R.F. (2007): Methylmercury-induced changes in mitochondrial function in striatal synaptosomes are calcium-dependent and ROS-independent. Neurotoxicology, 28, 720726.

Farina, M., Aschner, M. and Rocha, J.B. (2011): Oxidative stress in MeHg-induced neurotoxicity. Toxicol. Appl. Pharmacol., 256, 405-417.

Farina, M., Campos, F., Vendrell, I., Berenguer, J., Barzi, M., Pons, S. and Suñol, C. (2009): Probucol increases glutathione peroxidase-1 activity and displays long-lasting protection against methylmercury toxicity in cerebellar granule cells. Toxicol. Sci., 112 416-426.

Farina, M., Dahm, K.C., Schwalm, F.D., Brusque, A.M., Frizzo, M.E., Zeni, G., Souza, D.O. and Rocha, J.B. (2003a): Methylmercury increases glutamate release from brain synaptosomes and 
glutamate uptake by cortical slices from suckling rat pups: modulatory effect of ebselen. Toxicol. Sci., 73, 135-140.

Farina, M., Frizzo, M.E., Soares, F.A., Schwalm, F.D., Dietrich, M.O., Zeni, G., Rocha, J.B. and Souza, D.O. (2003b): Ebselen protects against methylmercury-induced inhibition of glutamate uptake by cortical slices from adult mice. Toxicol. Lett., 144, 351-357.

Faro, L.R., do Nascimento, J.L., Alfonso, M. and Durán, R. (2002): Mechanism of action of methylmercury on in vivo striatal dopamine release. Possible involvement of dopamine transporter. Neurochem. Int., 40, 455-465.

Faro, L.R., do Nascimento, J.L., Campos, F., Vidal, L., Alfonso, M. and Durán, R. (2005): Protective effects of glutathione and cysteine on the methylmercury-induced striatal dopamine release in vivo. Life Sci., 77, 444-451.

Faro, L.R., do Nascimento, J.L., San José, J.M., Alfonso, M. and Durán, R. (2000): Intrastriatal administration of methylmercury increases in vivo dopamine release. Neurochem. Res., 25, 225229.

Fonfría, E., Rodríguez-Farré, E. and Suñol, C. (2001): Mercury interaction with the GABA(A) receptor modulates the benzodiazepine binding site in primary cultures of mouse cerebellar granule cells. Neuropharmacology, 41, 819-833.

Fonnum, F. and Lock, E.A. (2004): The contributions of excitotoxicity, glutathione depletion and DNA repair in chemically induced injury to neurones: exemplified with toxic effects on cerebellar granule cells. J. Neurochem., 88, 513-531.

Franco, J.L., Posser, T., Dunkley, P.R., Dickson, P.W., Mattos, J.J., Martins, R., Bainy, A.C., Marques, M.R., Dafre, A.L. and Farina, M. (2009): Methylmercury neurotoxicity is associated with inhibition of the antioxidant enzyme glutathione peroxidase. Free Radic. Biol. Med., 47, 449-457.

Freitas, A.J., Rocha, J.B., Wolosker, H. and Souza, D.O. (1996): Effects of $\mathrm{Hg}^{2+}$ and $\mathrm{CH}_{3} \mathrm{Hg}^{+}$on $\mathrm{Ca}^{2+}$ fluxes in rat brain microsomes. Brain Res., 738, 257-264.

Garg, T.K. and Chang, J.Y. (2006): Methylmercury causes oxidative stress and cytotoxicity in microglia: attenuation by 15 -deoxydelta 12, 14-prostaglandin J2. J. Neuroimmunol., 171, 17-28.

Glaser, V., Nazari, E.M., Müller, Y.M., Feksa, L., Wannmacher, C.M., Rocha, J.B., de Bem, A.F., Farina, M. and Latini, A. (2010): Effects of inorganic selenium administration in methylmercury-induced neurotoxicity in mouse cerebral cortex. Int. J. Dev. Neurosci., 28, 631-637.

Halliwell, B. (1992): Reactive oxygen species and the central nervous system. J. Neurochem., 59, 1609-1623.

Hare, M.F., McGinnis, K.M. and Atchison, W.D. (1993): Methylmercury increases intracellular concentrations of $\mathrm{Ca}^{++}$and heavy metals in NG108-15 cells. J. Pharmacol. Exp. Ther., 266, 16261635.

Hirooka, T., Fujiwara, Y., Shinkai, Y., Yamamoto, C., Yasutake, A., Satoh, M., Eto, K. and Kaji, T. (2010): Resistance of human brain microvascular endothelial cells in culture to methylmercury: cell-density-dependent defense mechanisms. J. Toxicol. Sci., 35, 287-294.

Hirota, Y., Yamaguchi, S., Shimojoh, N. and Sano, K.I. (1980): Inhibitory effect of methylmercury on the activity of glutathione peroxidase. Toxicol. Appl. Pharmacol., 53, 174-176.

Hwang, G.W., Hayashi, T., Kita, K., Takahashi, T., Kuge, S. and Naganuma, A. (2007): siRNA-mediated inhibition of phosphatidylinositol glycan Class B (PIGB) confers resistance to methylmercury in HEK293 cells. J. Toxicol. Sci., 32, 581-583.

Hwang, G.W., Kimura, Y., Takahashi, T., Lee, J.Y. and Naganuma,
A. (2012a): Identification of deubiquitinating enzymes involved in methylmercury toxicity in Saccharomyces cerevisiae. J. Toxicol. Sci., 37, 1287-1290.

Hwang, G.W., Lee, J.Y., Kim, M.S., Sato, M., Takahashi, T. and Naganuma, A. (2013a): Changes in the levels of low molecular weight metabolites in the mouse cerebellum following treatment with methylmercury. J. Toxicol. Sci., 38, 703-706.

Hwang, G.W., Lee, J.Y., Ryoke, K., Matsuyama, F., Kim, J.M., Takahashi, T. and Naganuma, A. (2011a): Gene expression profiling using DNA microarray analysis of the cerebellum of mice treated with methylmercury. J. Toxicol. Sci., 36, 389-391.

Hwang, G.W., Mastuyama, F., Takahashi, T., Lee, J.Y. and Naganuma, A. (2013b): Deletion of the ubiquitin-conjugating enzyme Ubc2 confers resistance to methylmercury in budding yeast by promoting Whi2 degradation. J. Toxicol. Sci., 38, 301303.

Hwang, G.W. and Naganuma, A. (2006): DNA microarray analysis of transcriptional responses of human neuroblastoma IMR-32 cells to methylmercury. J. Toxicol. Sci., 31, 537-538.

Hwang, G.W., Ogiwara, Y., Takahashi, T. and Naganuma, A. (2012b): Ubiquitin-conjugating enzyme Cdc34 mediates methylmercury resistance in Saccharomyces cerevisiae by increasing Whi2 degradation. J. Toxicol. Sci., 37, 1283-1286.

Hwang, G.W., Oh, S.E., Takahashi, T., Lee, J.Y. and Naganuma, A. (2010a): siRNA-mediated knockdown of the melanocortin 2 receptor accessory protein 2 (MRAP2) gene confers resistance to methylmercury on HEK293 cells. J. Toxicol. Sci., 35, 947-950.

Hwang, G.W., Ryoke, K., Lee, J.Y., Takahashi, T. and Naganuma, A. (2011b): siRNA-mediated silencing of the gene for heat shock transcription factor 1 causes hypersensitivity to methylmercury in HEK293 cells. J. Toxicol. Sci., 36, 851-853.

Hwang, G.W., Ryoke, K., Takahashi, T. and Naganuma, A. (2010b): Silencing of the gene for homeobox protein HOXB13 by siRNA confers resistance to methylmercury on HEK293 cells. J. Toxicol. Sci., 35, 941-944.

Hwang, G.W., Tobita, M., Takahashi, T., Kuge, S., Kita, K. and Naganuma, A. (2010c): siRNA-mediated AMPKalpha1 subunit gene PRKAA1 silencing enhances methylmercury toxicity in HEK293 cells. J. Toxicol. Sci., 35, 601-604.

Hwang, G.W., Wada, N., Kuge, S. and Naganuma, A. (2009): Overexpression of the novel F-box protein Ymr258c confers resistance to methylmercury in Saccharomyces cerevisiae. J. Toxicol. Sci., 34, 413-416.

Ida, T., Sawa, T., Ihara, H., Tsuchiya, Y., Watanabe, Y., Kumagai, Y., Suematsu, M., Motohashi, H., Fujii, S., Matsunaga, T., Yamamoto, M., Ono, K., Devarie-Baez, N.O., Xian, M., Fukuto, J.M. and Akaike, T. (2014): Reactive cysteine persulfides and S-polythiolation regulate oxidative stress and redox signaling. Proc. Natl. Acad. Sci. USA, 111, 7606-7611.

Jacob, H.S. and Jandl, J.H. (1962): Effects of sulfhydryl inhibition on red blood cells. I. Mechanism of hemolysis. J. Clin. Invest., 41, 779-792.

Jones, D.P. (2008): Radical-free biology of oxidative stress. Am. J. Physiol. Cell Physiol., 295, C849-868.

Kanda, H., Sumi, D., Endo, A., Toyama, T., Chen, C.L., Kikushima, M. and Kumagai, Y. (2008): Reduction of arginase I activity and manganese levels in the liver during exposure of rats to methylmercury: a possible mechanism. Arch. Toxicol., 82, 803-808.

Kanda, H., Toyama, T., Shinohara-Kanda, A., Iwamatsu, A., Shinkai, Y., Kaji, T., Kikushima, M. and Kumagai, Y. (2012): S-Mercuration of rat sorbitol dehydrogenase by methylmercury causes its aggregation and the release of the zinc ion from the active site. 
Protein $S$-mercuration and toxic effects by methylmercury

Arch. Toxicol., 86, 1693-1702.

Katusz, R.M., Bono, B. and Colman, R.F. (1992): Affinity labeling of Cys111 of glutathione S-transferase, isoenzyme 1-1, by S-(4-bromo-2,3-dioxobutyl)glutathione. Biochemistry, 31, 89848990.

Kim, M.S., Takahashi, T., Lee, J.Y., Hwang, G.W. and Naganuma, A. (2012): Methylmercury induces CCL2 expression through activation of NF- $\mathrm{kB}$ in human $1321 \mathrm{~N} 1$ astrocytes. J. Toxicol. Sci., 37, 1275-1278

Kim, M.S., Takahashi, T., Lee, J.Y., Hwang, G.W. and Naganuma, A. (2013): Global chemokine expression in methylmercurytreated mice: methylmercury induces brain-specific expression of CCL3 and CCL4. J. Toxicol. Sci., 38, 925-929.

Kinoshita, Y., Ohnishi, A., Kohshi, K. and Yokota, A. (1999): Apparent diffusion coefficient on rat brain and nerves intoxicated with methylmercury. Environ. Res., 80, 348-354.

Kiskin, N.I., Krishtal, O.A., Tsyndrenko, AYa and Akaike, N. (1986): Are sulfhydryl groups essential for function of the glutamate-operated receptor-ionophore complex? Neurosci. Lett., 66, 305-310.

Kromidas, L., Trombetta, L.D. and Jamall, I.S. (1990): The protective effects of glutathione against methylmercury cytotoxicity. Toxicol. Lett., 51, 67-80.

Kumagai, Y., Homma-Takeda, S., Shinyashiki, M. and Shimojo, N. (1997): Alterations in Superoxide Dismutase Isozymes by Methylmercury. Appl. Organomet. Chem., 11, 635-643.

Kumagai, Y., Kanda, H., Shinkai, Y. and Toyama, T. (2013): The role of the Keap1/Nrf2 pathway in the cellular response to methylmercury. Oxid. Med. Cell. Longev., 2013, 848279.

Kumagai, Y., Shinkai, Y., Miura, T. and Cho, A.K. (2012): The chemical biology of naphthoquinones and its environmental implications. Annu. Rev. Pharmacol. Toxicol., 52, 221-247.

Kumagai, Y. and Sumi, D. (2007): Arsenic: signal transduction, transcription factor, and biotransformation involved in cellular response and toxicity. Annu. Rev. Pharmacol. Toxicol., 47, 243262.

Laube, B., Kuryatov, A., Kuhse, J. and Betz, H. (1993): Glycineglutamate interactions at the NMDA receptor: role of cysteine residues. FEBS Lett., 335, 331-334.

LeBel, C.P., Ali, S.F. and Bondy, S.C. (1992): Deferoxamine inhibits methyl mercury-induced increases in reactive oxygen species formation in rat brain. Toxicol. Appl. Pharmacol., 112, 161-165.

LeBel, C.P., Ali, S.F., McKee, M. and Bondy, S.C. (1990): Organometal-induced increases in oxygen reactive species: the potential of 2',7'-dichlorofluorescin diacetate as an index of neurotoxic damage. Toxicol. Appl. Pharmacol., 104, 17-24.

Lee, J.Y., Hwang, G.W., Kim, M.S., Takahashi, T. and Naganuma, A. (2012): Methylmercury induces a brain-specific increase in chemokine CCL4 expression in mice. J. Toxicol. Sci., 37, 12791282.

Lee, J.Y., Hwang, G.W. and Naganuma, A. (2009): Rip1 enhances methylmercury toxicity through production of reactive oxygen species (ROS) in budding yeast. J. Toxicol. Sci., 34, 715-717.

Levonen, A.L., Hill, B.G., Kansanen, E., Zhang, J. and Darley-Usmar, V.M. (2014): Redox regulation of antioxidants, autophagy, and the response to stress: Implications for electrophile therapeutics. Free Radic. Biol. Med., 71C, 196-207.

Limke, T.L. and Atchison, W.D. (2002): Acute exposure to methylmercury opens the mitochondrial permeability transition pore in rat cerebellar granule cells. Toxicol. Appl. Pharmacol., 178, 52-61.

Limke, T.L., Bearss, J.J. and Atchison, W.D. (2004): Acute expo- sure to methylmercury causes $\mathrm{Ca}^{2+}$ dysregulation and neuronal death in rat cerebellar granule cells through an M3 muscarinic receptor-linked pathway. Toxicol. Sci., 80, 60-68.

Limke, T.L., Otero-Montañez, J.K. and Atchison, W.D. (2003): Evidence for interactions between intracellular calcium stores during methylmercury-induced intracellular calcium dysregulation in rat cerebellar granule neurons. J. Pharmacol. Exp. Ther., 304, 949-958.

Lobanov, A.V., Hatfield, D.L. and Gladyshev, V.N. (2009): Eukaryotic selenoproteins and selenoproteomes. Biochim. Biophys. Acta., 1790, 1424-1428.

Magour, S. (1986): Studies on the inhibition of brain synaptosomal $\mathrm{Na}^{+} / \mathrm{K}^{+}$-ATPase by mercury chloride and methyl mercury chloride. Arch. Toxicol. Suppl., 9, 393-396.

Manfroi, C.B., Schwalm, F.D., Cereser, V., Abreu, F., Oliveira, A., Bizarro, L., Rocha, J.B., Frizzo, M.E., Souza, D.O. and Farina, M. (2004): Maternal milk as methylmercury source for suckling mice: neurotoxic effects involved with the cerebellar glutamatergic system. Toxicol. Sci., 81, 172-178.

Matsuda, Y., Higashiyama, S., Kijima, Y., Suzuki, K., Kawano, K., Akiyama, M., Kawata, S., Tarui, S., Deutsch, H.F. and Taniguchi, N. (1990): Human liver manganese superoxide dismutase. Purification and crystallization, subunit association and sulfhydryl reactivity. Eur. J. Biochem., 194, 713-720.

Mekahli, D., Bultynck, G., Parys, J.B., De Smedt, H. and Missiaen, L. (2011): Endoplasmic-reticulum calcium depletion and disease. Cold Spring Harb. Perspect. Biol., 3, 1-30.

Minnema, D.J., Cooper, G.P. and Greenland, R.D. (1989): Effects of methylmercury on neurotransmitter release from rat brain synaptosomes. Toxicol. Appl. Pharmacol., 99, 510-521.

Miura, K. and Imura, N. (1987): Mechanism of methylmercury cytotoxicity. Crit. Rev. Toxicol., 18, 161-188.

Miura, K., Koide, N., Himeno, S., Nakagawa, I. and Imura, N. (1999): The involvement of microtubular disruption in methylmercury-induced apoptosis in neuronal and nonneuronal cell lines. Toxicol. Appl. Pharmacol., 160, 279-288.

Miura, N., Kaneko, S., Hosoya, S., Furuchi, T., Miura, K., Kuge, S. and Naganuma, A. (1999): Overexpression of L-glutamine:Dfructose-6-phosphate amidotransferase provides resistance to methylmercury in Saccharomyces cerevisiae. FEBS Lett., 458, 215-218.

Mori, N., Yasutake, A. and Hirayama, K. (2007): Comparative study of activities in reactive oxygen species production/defense system in mitochondria of rat brain and liver, and their susceptibility to methylmercury toxicity. Arch. Toxicol., 81, 769-776.

Murayama, A., Raffin, J.P., Remy, P. and Ebel, J.P. (1975): Yeast phenylalanyl-tRNA synthetase: properties of the sulfhydryl groups; evidence for -SH requirement in tRNA acylation. FEBS Lett., 53, 15-22.

Naganuma, A., Miura, N., Kaneko, S., Mishina, T., Hosoya, S., Miyairi, S., Furuchi, T. and Kuge, S. (2000): GFAT as a target molecule of methylmercury toxicity in Saccharomyces cerevisiae. FASEB J., 14, 968-972.

Naganuma, A., Miura, K., Tanaka-Kagawa, T., Kitahara, J., Seko, Y., Toyoda, H. and Imura, N. (1998): Overexpression of manganese-superoxide dismutase prevents methylmercury toxicity in HeLa cells. Life Sci., 62, PL157-161.

Nishida, M., Sawa, T., Kitajima, N., Ono, K., Inoue, H., Ihara, H., Motohashi, H., Yamamoto, M., Suematsu, M., Kurose, H., van der Vliet, A., Freeman, B.A., Shibata, T., Uchida, K., Kumagai, Y. and Akaike, T. (2012): Hydrogen sulfide anion regulates redox signaling via electrophile sulfhydration. Nat. Chem. 
Biol., 8, 714-724.

Oliveira, R.B., Gomes-Leal, W., do-Nascimento, J.L. and PicançoDiniz, C.W. (1998): Methylmercury intoxication and histochemical demonstration of NADPH-diaphorase activity in the striate cortex of adult cats. Braz. J. Med. Biol. Res., 31, 1157-1161.

Oppedisano, F., Galluccio, M. and Indiveri, C. (2010): Inactivation by $\mathrm{Hg}^{2+}$ and methylmercury of the glutamine/amino acid transporter (ASCT2) reconstituted in liposomes: Prediction of the involvement of a CXXC motif by homology modelling. Biochem. Pharmacol., 80, 1266-1273.

Patel, E. and Reynolds, M. (2013): Methylmercury impairs motor function in early development and induces oxidative stress in cerebellar granule cells. Toxicol. Lett., 222, 265-272.

Peng, S., Hajela, R.K. and Atchison, W.D. (2002): Effects of methylmercury on human neuronal L-type calcium channels transiently expressed in human embryonic kidney cells (HEK-293). J. Pharmacol. Exp. Ther., 302, 424-432.

Ruppersberg, J.P., Stocker, M., Pongs, O., Heinemann, S.H., Frank, R. and Koenen, M. (1991): Regulation of fast inactivation of cloned mammalian IK(A) channels by cysteine oxidation. Nature, 352, 711-714.

Sager, P.R., Doherty, R.A. and Olmsted, J.B. (1983): Interaction of methylmercury with microtubules in cultured cells and in vitro. Exp. Cell Res., 146, 127-137.

Sakamoto, M., Ikegami, N. and Nakano, A. (1996): Protective effects of $\mathrm{Ca}^{2+}$ channel blockers against methyl mercury toxicity. Pharmacol. Toxicol., 78, 193-199.

Sarafian, T.A. (1993): Methyl mercury increases intracellular $\mathrm{Ca}^{2+}$ and inositol phosphate levels in cultured cerebellar granule neurons. J. Neurochem., 61, 648-657.

Shanker, G. and Aschner, M. (2001): Identification and characterization of uptake systems for cystine and cysteine in cultured astrocytes and neurons: evidence for methylmercury-targeted disruption of astrocyte transport. J. Neurosci. Res., 66, 998-1002.

Shimai, S. and Satoh, H. (1985): Behavioral teratology of methylmercury. J. Toxicol. Sci., 10, 199-216.

Shinyashiki, M., Kumagai, Y., Homma-Takeda, S., Nagafune, J., Takasawa, N., Suzuki, J., Matsuzaki, I., Satoh, S., Sagai, M. and Shimojo, N. (1996): Selective inhibition of the mouse brain MnSOD by methylmercury. Environ. Toxicol. Pharmacol., 2, 359366.

Sidhu, A., Kassis, S., Kebabian, J. and Fishman, P.H. (1986): Sulfhydryl group(s) in the ligand binding site of the D-1 dopamine receptor: specific protection by agonist and antagonist. Biochemistry, 25, 6695-6701.

Simpson, R.B. (1961): Association constants of methylmercury with sulfhydryl and other bases. J. Am. Chem. Soc., 83, 4711-4717.

Sirois, J.E. and Atchison, W.D. (2000): Methylmercury affects multiple subtypes of calcium channels in rat cerebellar granule cells. Toxicol. Appl. Pharmacol., 167, 1-11.

Stringari, J., Nunes, A.K., Franco, J.L., Bohrer, D., Garcia, S.C., Dafre, A.L., Milatovic, D., Souza, D.O., Rocha, J.B., Aschner, M. and Farina, M. (2008): Prenatal methylmercury exposure hampers glutathione antioxidant system ontogenesis and causes long-lasting oxidative stress in the mouse brain. Toxicol. Appl. Pharmacol., 227, 147-154.

Takahashi, T., Kim, M.S., Saito, T., Lee, J.Y., Hwang, G.W. and Naganuma, A. (2013): Brain-specific induction of secretoglobin $3 \mathrm{~A} 1$ expression in mice treated with methylmercury. J.
Toxicol. Sci., 38, 963-965.

Tan, X.X., Tang, C., Castoldi, A.F., Manzo, L. and Costa, L.G. (1993): Effects of inorganic and organic mercury on intracellular calcium levels in rat T lymphocytes. J. Toxicol. Environ. Health, 38, $159-170$.

Toyama, T., Shinkai, Y., Kaji, T. and Kumagai, Y. (2013): Convenient method to assess chemical modification of protein thiols by electrophilic metals. J. Toxicol. Sci., 38, 477-484.

Toyama, T., Yoshida, E., Shinkai, Y. and Kumagai, Y. (2011): DNA microarray analysis of human neuroblastoma SH-SY5Y cells exposed to methylmercury. J. Toxicol. Sci., 36, 843-845.

Trotti, D., Danbolt, N.C. and Volterra, A. (1998): Glutamate transporters are oxidant-vulnerable: a molecular link between oxidative and excitotoxic neurodegeneration? Trends Pharmacol. Sci., 19, 328-334.

Trotti, D., Nussberger, S., Volterra, A. and Hediger, M.A. (1997a): Differential modulation of the uptake currents by redox interconversion of cysteine residues in the human neuronal glutamate transporter EAAC1. Eur. J. Neurosci., 9, 2207-2212.

Trotti, D., Rizzini, B.L., Rossi, D., Haugeto, O., Racagni, G., Danbolt, N.C. and Volterra, A. (1997b): Neuronal and glial glutamate transporters possess an SH-based redox regulatory mechanism. Eur. J. Neurosci., 9, 1236-1243.

Wagner, C., Sudati, J.H., Nogueira, C.W. and Rocha, J.B. (2010): In vivo and in vitro inhibition of mice thioredoxin reductase by methylmercury. Biometals, 23, 1171-1177.

Yasutake, A., Nakano, A., Miyamoto, K. and Eto, K. (1997): Chronic effects of methylmercury in rats. I. Biochemical aspects. Tohoku J. Exp. Med., 182, 185-196.

Yee, S. and Choi, B.H. (1994): Methylmercury poisoning induces oxidative stress in the mouse brain. Exp. Mol. Pathol., 60, 188196.

Yin, Z., Milatovic, D., Aschner, J.L., Syversen, T., Rocha, J.B., Souza, D.O., Sidoryk, M., Albrecht, J. and Aschner, M. (2007): Methylmercury induces oxidative injury, alterations in permeability and glutamine transport in cultured astrocytes. Brain Res., 1131, 1-10.

Yonaha, M., Saito, M. and Sagai, M. (1983): Stimulation of lipid peroxidation by methyl mercury in rats. Life Sci., 32, 15071514.

Yoshida, E., Toyama, T., Shinkai, Y., Sawa, T., Akaike, T. and Kumagai, Y. (2011): Detoxification of methylmercury by hydrogen sulfide-producing enzyme in mammalian cells. Chem. Res. Toxicol., 24, 1633-1635.

Yoshino, Y., Mozai, T. and Nakao, K. (1966): Biochemical changes in the brain in rats poisoned with an alkymercury compound, with special reference to the inhibition of protein synthesis in brain cortex slices. J. Neurochem., 13, 1223-1230.

Vogel, D.G., Margolis, R.L. and Mottet, N.K. (1985): The effects of methyl mercury binding to microtubules. Toxicol. Appl. Pharmacol., 80, 473-486.

Vogel, D.G., Margolis, R.L. and Mottet, N.K. (1989): Analysis of methyl mercury binding sites on tubulin subunits and microtubules. Pharmacol. Toxicol., 64, 196-201.

Zhang, Y., Lu, R., Liu, W., Wu, Y., Qian, H., Zhao, X., Wang, S., Xing, G., Yu, F. and Aschner, M. (2013): Hormetic effects of acute methylmercury exposure on grp78 expression in rat brain cortex. Dose Response, 11, 109-120. 